\title{
Sri Lankan Tamil Refugee Women in India
}

\author{
Asha Hans
}

\begin{abstract}
The author describes the situation of displaced and refugee Sri Lankan Tamil women in camps in India. Gender, ethnicity, class status, religion, social roles and security of the person are central to this analysis of women's experiences of war as contrasted with the situation of men. The significance of clashing cultures and divergent social norms to the everyday lives of these women is highlighted. The plight of these women is linked to refugee policy and international conventions that are not salient to the actual lived experience in the camps, and some directions for change are indicated.

\section{Précis}

L'auteure décrit la situation des réfugiées tamoules du Sri Lanka dans les camps indiens. Cette analyse compare le vécu des femmes dans un contexte de guerre à celui des hommes, en s'attachant particulièrement aux questions de sexe, d'ethnicité, de classe, de religion, de rôles sociaux et de sécurité personnelle. L'impact des divergences culturelles et socio-normatives sur le quotidien y est souligné. La situation critique de ces femmes est imputée aux politiques et conventions internationales sur les réfugié(e)s qui ne tiennent aucunement compte de la réalité des la vie dans les camps. L'auteure suggère des changements.

Women and children form the majority of refugee populations anywhere. In India, this dyad of Sri Lankan refugees conforms to the pattern. To examine the Sri Lankan refugee women's status in India, a valuable starting

Asha Hans is Associate Professor, Department of Political Science, and Coordinator, Centre for Women's Studies and Development Programmes, Utkal University, Vani Vihar, Bhubaneswar, India. point is by looking at the refugee women's place in the existing power structures. Research on women's studies has noted two aspects of women refugees. They are at the same time vulnerable and indomitable. Uprooted by conflict they are the most affected refugee group. Women, whether raped, secluded, unable to feed their children, or abducted, are victims of war and suffer physically, psychologically, and spiritually. Stripped of material possessions, dignity and self-esteem, they bring with them into exile the trauma of sexual violation, of helplessly watching their children die, or of being continually stalked by violence (Mayotte 1992, 146-50). Though vulnerable in some ways, they are also seen as the backbone of the refugee community, as Judy Mayotte herself ascertains: "they are the ones who must reestablish the family in exile, so too will they be the ones to recreate the familial environment on return to the homeland" (ibid., 189). Researchers have noted that women play a more active role in exile than men. Universally, refugee women are responsible for domestic work, have to cope with changed family structures as heads of family households and also maintain their traditional culture leaving men with passive roles (Forbes 1991, 8-9). The Sri Lankan refugee women's role is studied keeping this in view and especially their socioeconomic, political and cultural environment in Sri Lanka and refuge in an ethnically similar region in India.

\section{Tamil Women in Sri Lanka}

Women in Sri Lanka, as in other parts of the world, have tried to break barriers put up by society which place them at the bottom of the power structure. Their position in an independent Sri Lanka remains virtually unchanged. They have been shackled by cultural morals and traditional values
(Wickrematunge 1995, 12). Though they were the first group to be granted adult suffrage in Asia, their lives were constrained by political and social discrimination.

This study provides an insight into the social construction of refugee women before coming to India. Family remains the primary unit of the Tamil social system. This family, as in most traditional societies, is an "extended family." The society despite a matriarchal form is patriarchal in character. Tamil women, who came to India as part of the above streams of refugees, have been like most women, worldwide, victims of social oppression. The Sri Lankan Tamil had also to face ethnic discrimination as well as oppression by caste and class structures. Among the Sri Lankan Tamils the lower castes, for instance were not allowed to interact with the higher castes (Dias 1979, 9). This socioreligious feature found continuity across the straits in Tamil Nadu.

Despite caste restrictions, Sri Lankan law gave equality to its women. Legal protection to the Tamil Hindu women is provided by Thesavalami or "Customs of the Land" law of the Tamils. It is a collection of customs of Jaffna Tamils made under the Dutch Governor, General Simons, in 1706-1707. The codification was carried out later and approved by the native chiefs. The British included it as law under Regulation 1806 (Goody and Tambiah 1973, 111-13). Thesavalami refers to three types of property ownership, that given as dowry to the daughter by the parents (chidam), property inherited by male members from parents (muthusam), and property acquired by the married couple (thedathaddam). Thesavalami stipulates that chidam or hereditary property brought by the wife was to be transferred to her daughters alone at marriage as their dowry (Goody and

Refuge, Vol. 16, No. 2 (June 1997) 
Tambiah 1973, 112-13). Thesavalami today has lost its traditional characteristics. Grossholtz argues that, in its pursuit of creating capitalist and colonialist structures to establish private ownership of property and accumulation of capital, the colonial governments gradually replaced traditional norms. The government took away land to which ownership had not been firmly established. By this act over the years 1901-1921,50 percent of women landowners lost their paddy fields (Grossholtz 1984, 115). Consequently, they lost their social equality. Today, land constitutes a part of the dowry and is settled in the name of the woman though she has no right to sell it without her husband's consent as long as she is married.

Compared to the Tamilian in India, a Sri Lankan Tamil is governed by more liberal rights. The Indian Tamil woman has no right over land and land is not part of her dowry. Goody and Tambiah see the Sri Lankan system both as variants of the classical Indian model and a systemic transformation of that model. It was progressive in its attitude to women's rights and the important constraints that entered the legal system are traceable to English law or Roman-Dutch law (Goonesekera 1990, 154). The Tamil Muslims are guided by Islamic law. It is purely patriarchal where a woman has no right over property (ibid., 1990).

The socially-oppressed Tamil woman refugee is the product of a sociopolitical revolution which has not been paid much attention. The social status of the women related to their political role and its impact on refugees is clearly the least researched area. Women do play an important role in freedom and peace movements (Heng 1997, Vickers 1993, Yuval-Davis 1989, Jayawardena 1986) though their situations very rarely change after the revolutions are over (Einhorn 1993, Sharara 1983, Rady 1994, Diamond 1996). In the Sri Lankan case, Jayawardena argues that the women's movement did not take off because the Sri Lankan women had no atrocities to fight against (Jayawardena 1986, 136). Insurgent movements in developing countries, make use of the issue of social oppression to recruit women to their revolutionary causes. This was also the case in Sri Lanka. Many of these women joined militancy movements to fight for a national cause, as well as to get away from social oppression. This strategy provided them with a short cut to emancipation. There are many who joined these causes due to human rights abuse, primarily sexual, by state forces while fighting militancy. The refugee women from many conflict areas who have joined revolutionary movements are the products of such rationality, which has political implications for both the host and sending countries.

The persecution of women has enabled insurgents to draw them into revolutionary movements. Encouraging women's participation in the struggle for freedom relates it to bringing in radical changes in their lives. Consciousness of women is considered as vital to their "social emancipation." The Sri Lankan Tamil women's participation in the political struggle as the Liberation Tigers of Tamil Eelam (LTTE) "provides a springboard from which women can organize, identify and articulate their grievances and fight against the modes of oppression and exploitation perpetrated on them (Balasingham 1983, 30). The dedicated freedom fighter at some stage becomes a refugee. Women could be simultaneously militants and refugees. Joining the freedom movement provides a chance for women to attain social emancipation and mobilization. As freedom fighters, they achieve a social status equal to men.

The persecution of Tamil women in Sri Lanka enabled the LTTE to draw them into the insurgency movement. The LTTE has a separate fighting force of women. Akila, the leader of this force was supposed to be high in the LTTE hierarchy before her death in 1996. Most of these "Freedom Birds" are in their teens. Encouraging their participation in the struggle for Eelam, the LTTE's commitment was to bring in radical changes in the lives and consciousness of women which they consider to be vital to their "social emancipation" (ibid., 30). The choice of militancy by some women and its relationship to refugee status becomes clearer. This was especially surprising because in comparison to other South Asian women, Sri Lankan women have had the advantage of high literacy rates and health status. Sri Lanka can also boast of two women as heads of states. It was obvious that despite the existence of a good welfare system, and the election of Srimavo Bandarnaike and Chandrika Kumartunge to the highest office of the country, most Sri Lankan women face discrimination in sociopolitical and economic spheres. The twelve women who sit in Parliament today are there as a result of the violent slaying of either their husbands or their fathers (Wickremtunge 1995, 11). Tamil women though confronted with different problems than their Sinhalese counterparts, also face the same discriminations (Jayawardena 1986, 109-36; Skjonsberg 1982,322-25). The Sri Lankan scenario confirms this even today where only two Tamil women have entered Parliament and both of those by default. Rasamanohari Pulendran was elected after her husband was assassinated, and Ranganyagi Pathmanathen when her brother died. Both won due to sympathy votes.

In conflict situations, women have always been considered part of the spoils of war. This has recently drawn attention of researchers again (Tetreault 1993; Gallin, Ferguson, and Harper 1995). Where women are concerned the most important issue in war is that of sexual violence. Women constituting 50 percent of the population and caught up in the Tamil struggle for Eelam were equal victims of this first wave of organized racial assault by the Sri Lankan state (Balasingham 1983, 23). The Tamil women confronted with a conflict situation faced new challenges. According to the LTTE, the target of this ethnic violence were particularly women who "suffered the 
worst forms of cruelty and indignity. Women have been the targets of the most vicious and hideous combination of racism and sexism-rape" (ibid., 23). Rape in conflict situations is common. Though under Sri Lankan law, a rapist can face up to twenty years imprisonment, social condemnation of victims prohibits them from seeking legal justice. This is the case in even a non-conflict situation. The male-dominated judiciary see the victim of rape as having invited it upon herself and not worthy of special consideration (Wijayatilake 1992, 31).

There is no trauma worse than sexual assault for a woman. Women all over the world are targets of this offence and state boundaries do not change the way a woman feels. What is different is the way society accepts the victims of sexual violence. In many developing countries including Sri Lanka...sexual violence is not only a personal trauma, but also has a social stigma attached to it. A woman violated sexually becomes socially outcast. It is not only the community which rejects her but also her husband and family. Rape victims are ostracized for life. This is much more among middle class or rich families. They hide the truth so that the young woman is saved from a life long imprisonment without walls. Tamil society has shown insensitivity towards women who have been sexually-abused during ethnic conflict (Hoole 1990, 31819). The result is that non-recognition of the act of rape leaves the woman alone with a trauma. The rape victimizes a woman; the society destroys her totally (ibid., 319). In fact, society in these countries blames the woman and not the oppressor, laying the blame at the door of the victim, thus reflecting the social structure where women's roles are always secondary.

Rape was carried out against the Tamil women, not only by the Sinhalese soldiers but also by the Indian Peacekeeping Force (IPKF) sent in 1987 to Sri Lanka. Lt. General Depinder Singh, the overall commander of the IPKF in Sri Lanka, defending his men, refused to believe that Indian men would ever "go berserk to the extent of raping or killing women as it was against the Indian ethos and culture" (Bobb, Vankatramani, and Rehman 1987, 38). Their pleas of innocence were upset when it was highlighted that Dhanu, the suicide bomber, who assassinated Indian Prime Minister Rajiv Gandhi, in 1991 had been presumably raped by the IPKF. The IPKF like the LTTE also found in women a group ready to take to arms. These women together with other cadre members became targets of LTTE wrath. Consequently they joined the IPKF and its allied insurgent groups. The trauma of Indian atrocities committed on Sri Lankan women were to leave their mark, as the killing by Dhanu demonstrated.

Though being a woman has laid them open to sexual attacks, women's response to the war has not been only as followers in the insurgent movement. Uneducated women from Sri Lanka's lowest income groups braved the wrath of the militants, when internecine rivalry split the movement and brought violence into the lives of the Tamils themselves. In this battle it was a group of women from the villages who used chili powder, knives and rice pounders to challenge the LTTE and other insurgent groups. The "natural defiance of the women from the lower classes remained a remarkable feature as opposed to the pliability of upper class women" (Hoole 1990, 92). Among the Sinhalese, a few women's organizations were formed which were a reflection of the situation prevailing in the country. Among these were the Mothers' Front, a movement of women protesting against the disappearance of their children (United Nations, Economic and Social Council, 1991 E/CN.4/1991/SR.42: 16). It had a broad-based membership cutting across class and caste barriers and included women from both the urban and rural areas. A large membership enabled it to protest vigorously against the atrocities committed by the state and the militants. The above vulnerability and indomitable spirit of the
TamilSri Lankan women was reflected in their behaviour in refuge.

\section{Refuge in India}

The Sri Lankan refugee women who arrived in India were under a dual burden-physical and psychological in nature. Many had been physically abused and had to face problems of exile. They were now faced with new challenges in a nation though ethnically the same, still foreign in many ways. The Sri Lankan Tamil is a funloving person, used to an open lifestyle. This is very unlike the life led by Tamil women in Tamil Nadu who live in a closed environment suppressed by family and society. The Sri Lankan women's open lifestyle caused misunderstandings and they were compelled to choose the lifestyle of the host community. Their style of dressing had to undergo change. Clothes worn by Sri Lankan Tamil women were western dresses or a tight blouse and a sarong. In Tamil Nadu sarees among older women and half sarees (a smaller saree over a long skirt) among the younger women was the tradition. To escape censure for not complying with Tamil cultural norms, the Sri Lankan women had to change their style of dress to suit local conditions. They now dressed more circumspectly and walked with more inhibition. Men, in contrast, needed no such change. Harassment of women in Sri Lanka, according to the refugee women was less. The Sri Lankan males extend more courtesy to women, and mixing with the opposite sex was not frowned upon. Widow remarriage was common.

In the camps, no discrimination in terms of sex is noticeable. A woman and frequently a single woman, takes over the role of camp spokesperson. At the same time, it cannot be overlooked that various structures of power exist in camps. The gender-biased power relation of the refugee as it existed in Sri Lanka continues in the camps. In addition, the institution of refugee administration extends the male-dominated structures into the camps. Women have to cope with familial and societal 
patriarchalnorms, the new male domination, and policies where refugees are stereotyped and programs are gender blind. Men continue to retain their dominant hierarchical position in refuge. This is despite their new economic roles where they have often lost their economic value. This loss has resulted in social problems, for example, they can lose control over their children. In all camps, the major burden of managing the family falls on the women. Besides the usual daily activities which keep them busy, they trek long distances to collect firewood. In some camps, there is no water, so they have to fetch water from a far. Some women do not approve of men helping in the households, though they themselves worked in the fields in Sri Lanka. It is therefore not surprising that they emerge as camp spokespersons, though not as camp leaders. Decision making still rests with the men. There is little change in attitudes among the older generation towards the patriarchal system which prevailed in Sri Lanka. Some changes have occurred among the younger couples who share work. Joint decisions are made within the family, though the important decisions are always made by the men.

Some women work outside the camps. Most of these women belong to the lower castes. The middle-class educated Sri Lankan refugee men do not allow their wives to work outside the camps. It is not only a case of middleclass morality, but the fact that work is available mostly for daily wage labourers in the agricultural and industrial sectors. Those who are compelled to do this work, besides the lower castes, are female heads-of-households who do not find the dole enough. Some women do admit that they contributed much more to household expenses in Sri Lanka than they do in the camps. The majority of refugees belonged to the agricultural and fishing sector. These occupations are dependent on family units pooling their resources where women played an important role. In India the economic roles are completely changed. The family as a unit in the camps does not exist most of the time. When it does, the family can no longer act as an economic unit as they have no lands, livestock or boats of their own. They are only dependent on wage labour.

Most women admit that the standard of living in Sri Lanka they were used to was much higher. Their access and control to resources in exile is limited. In recent years, although the use of women in refugee-organized welfare activities has increased and has given women an added advantage of meeting and discussing their problems, the final decision making does not rest with them. This has been noticed even in camps where the women are in a majority.

Fewer single women are found in the camps as the LTTE does not allow women under the age of twenty-five to leave Jaffna. These women according to the refugees are recruited into the insurgent forces. Several social problems exist. Many of the refugee women have been raped. When questioned on the issue, they sidetracked, it but did not refute the fact that the acts were committed or that it bothered them. At the same, time their silence, in itself, was an answer to the trauma suffered, even if not by them directly, but by other women in their own community. As one woman quietly explained, it was a bondage among women which went above any other issue. They did not start the war but in their struggle for Eelam, women were paying a higher price than men. The women saw the sexual attacks as an organized effort by security forces to desecrate Tamils as reprisal for the part played by the men in the war effort. The fear, alienation and betrayal combined to make them take steps to flee to safety. Some fled for personal reasons but most were part of a spontaneous move by large numbers to escape the brutality of security and armed forces.

Teenage pregnancy has been among other issues worrying the refugees. Teenage pregnancy is a common problem in the camps and support is provided, again, only through the health workers. No special program is run for it. Due to lack of privacy in the camps children grow up earlier than normal. Stress among adolescents has also contributed to the increase. This has been particularly noticed in divided families. It has to be kept in mind that many of the teenagers were either born in India in camps, or have spent their childhood there. Many have neither seen nor met their fathers or brothers. Forcing women into sexual relations by camp or Qbranch (security branch) officials is the exception rather than the rule. The women have been protected by the host Tamil society, which perceives the desecration of Tamil women as a heinous crime and against the norms of Tamil culture. Prostitution, which does exist, is frowned upon and hidden, but does not meet as much disapprobation as would otherwise be the case. The women pointed out that it was not due to economic reasons or boredom, but saw the act as a sort of waywardness of some young women. It was a revolt against their existing unnatural condition.

The divorce rate among the younger people has been on an upward trend, reflecting the increasing social instability in their lives. More women are opting for divorce than earlier. Break up of families, and resultant problems in bringing up children in exile has contributed to the escalation. The women also saw it is a result of the detachment from cultural moorings.

Psychological stress caused by separation among divided families is universal. Stress is caused by lack of knowledge of the conditions, or whereabouts of those left behind, complicated by a guilt complex that they themselves are in safe conditions, while other members continue to live in daily danger. This situation has contributed to rise in violence in the camps. The women have been most affected by it. Many have left behind their husbands and sons. The grief of those left behind and the loss of support from the extended families which they are used to, makes them extremely vulnerable to psychological stress. It has also caused an increase in wife battering. Some refugee families have been divided among camps in 
India. According to a Sri Lankan doctor, separation results in women becoming excessively possessive in nature creating further stress in the family.

Lack of social privacy has become a major problem for women in camps. Lack of bathrooms is a common feature. Even birth of children in some camps becomes an open visual affair. It affects the adolescent women especially who reach the stage of puberty in the camps. The puberty rituals, combined with lack of privacy in even washing sanitary cloth has escalated anxiety levels. Sanitary napkins are not supplied either by the government or the NGO's who work in the camps. In developing countries such as India where most of the local population lives below the poverty level these items are a luxury which only the rich can afford. Distribution of these by the government and NGO's would only create prejudices against the refugee population. The NGO's could as an alternate distribute cloth replacements and lay emphasis on sanitary infrastructure.

Sociocultural continuity has been found among the refugees, with the woman as the main protector of these practices. Childhood practices of piercing of the girls' ears and taking the child to the temple on the forty-first day continue. Puberty rights continue though with great difficulty as there is no privacy in most camps. Isolation becomes difficult, as does giving of a ceremonial bath, but it continues nevertheless. Female genital mutilation continues among the Muslims, though kept as a secret. Marriages are usually arranged, though an increasing trend in self arranged marriages is noticeable. During marriages, matching of horoscopes continues. Dowry is either provided or promised on return to Sri Lanka. The inability of the refugee to pay dowry has created a social upheaval. Women refugees who belonged to families, who could pay a dowry in Sri Lanka, have had to settle for lower class and out of caste marriages. Marriages have also been delayed for this reason. Though the daughters are given a dowry, they will not have legal access to their parent's property on return to Sri Lanka. Some insist that caste is a forgotten factor, but even among the Vellalla Christians, caste divisions exist, and related customs such as dowry and arranged marriages with matching of horoscopes is a common practise. The usual dowry, ranges among the lower middle classes from ten sovereigns (gold pieces), one to three acres of wet and dry land, to fewer number of sovereigns and cash. These promises can mostly be fulfilled on return.

Caste does not play a major role among the refugees as it does in Tamil Nadu. Confined spaces break down caste barriers in many ways. The Sri Lankan refugee woman, the conservator of the cultural identity of the family, is confronted with hard choices in refuge. This is more so in Tamil Nadu, where the caste structures are rigidly stratified, and gender roles are defined by caste and not class. As long as the refugee stays in India and does not want to be a figure of ridicule by the local Tamils, she has to follow similar sociocultural practices. This creates further stress in a life already traumatized by war, violence and uprooting. The very young are trying to break away from these pressures, to forge ahead, and make attempts at social mobilization through education. Education has become the most important factor in their lives in exile. Access to it provides them a space to challenge both gendered and social roles. Since 1991, after the assassination of Rajiv Gandhi by a Sri Lankan Tamil woman, this facility was withdrawn from camps. This constituted not only a contravention of the Right of the Child but also acted as an obstacle in women's attempt at social mobility.

The refugee women in the camps and outside the camps presented a profile of a community based on family values. Values were rooted in religious and social structures. The women existed within this milieu and in exile could get protection much more easily when they enveloped themselves within the confines of a traditional value system. Thus, when immediate family members were left behind, the women could depend on community members. In spite of the extension of this system in exile, there has been a disruption of both women's social roles and social organizations. Despite being part of a similar ethnic milieu, they are stateless, escapees from their own homes leaving behind family and material possessions. In exile both these losses become important determinants of their identities.

This transient life compels them to look at their future differently. Torn from their roots, they strive to keep themselves strong enough till they return and nurture their lives, the community and the state again. They see themselves as key figures in this future process, even though they recognize that they would not have the decisionmaking power equivalent to men. Seeing their men suffer both physically and psychologically, gives them the strength to fight and survive. Many of them try to hide their strength behind a veil of dependency so that they do not further impose psychological stress on their husbands by changing their socially defined roles. Protection of self respect and dignity of the family falls on the shoulders of the women in exile.

The Government of India does not develop its plans keeping this majority refugee population in mind. Whatever planning is there, is for provision of essentials, such as food, shelter, and education. Special needs of women are not given any attention. The Sri Lankan woman in India play an active role in exile. She runs her household, keeps the family together and carries out all cultural functions. All this is done despite the extra pressure she has to work under, which men do not. Nowhere did the refugee women mention that their problems were related to their secondary status in society. This is an accepted fact. They did not expect the policy makers to pay attention to theirneeds though they bear the major burden of work in the camps. 


\section{Return and Rehabilitation in Sri Lanka}

In 1992, the repatriation of the Sri Lankan refugees from India was initiated. In a reverse trend of refugee flows, men prefer to be repatriated before their wives and children. Thus, the large numbers of women repatriates who went later gave their reason as family unification. Women were not sent as they face physical insecurity especially sexual harassment and rape, and children being taken into custody and killed. Many refugee women in India who refused to return, referring to the conflict situation, based their knowledge on the situation in Sri Lanka, through letters received from family members and friends.

In the government-run prison-like barbed wire camps, women are increasingly found at the receiving end of violence in the camps, and have also been sexually abused in large numbers (Manushi 1995, 3). The refugee women in India feel that the kind of attention that should be paid to their needs is an issue that needs to be addressed. This becomes difficult in a situation where disclosure of sexual abuse by the victim becomes crucial. Where the predominant dynamic underlying any disclosure is stigmatization, more so in the social context, and where ignominy can be treated as licentiousness, strong deterrents to disclosure are in effect. Reported emotions are of fear, guilt, shame and anger, sometimes leading to suicide. As female virginity is equated to purity and virtue, the resultant trauma is augmented and any further inquiry can only aggravate the impact. The task becomes all the more difficult as patriarchal social arrangements ensure the continuation of power relations. In their perception, those in authority also tend to be insensitive to the question female dignity and security. The first step would be to sensitize the decision makers.

Refugee women in India showed a concern for the large number of widows in Sri Lanka, and the problems faced by them. Before the conflict began, if a woman lost her husband, she would receive a pension if her husband had been a civil servant, or would be looked after by a grandson, both of which are not possible now. Though the Sri Lankan government has a program that pays compensation, especially to women,- to widows or those who have lost grown sons, but "the cumbersome application process keeps many women from applying for or receiving the grants" (SEDEC 1993, 8; Nissan 1996, 27).

Writing on the displaced and refugee Sri Lankan women, the editors of a gender periodical, Manushi comment that as refugees these women are the victims or potential victims of human rights abuses and acts of aggression. They suffer not only from loss of protection from the government and social networks, but also from loss of normal access to food, shelter and livelihood (Manushi 1995, 3). The women also told stories of the hardships faced in camps: of having to walk several miles for water, to bathe and wash their clothes, and the lack of privacy (SEDEC 1993, 22; Nissan 1996, 27). A human rights worker who described conditions as "abominable" also noted women's attempts to make it more "tolerable." According to her, each little enclosure testified to the efforts of the people, in particular the women, to maintain some semblance of "normalcy" in the midst of this environment of despair and deprivation (Ruiz 1994, 12). At this stage of resettlement women are concerned with daily needs, and as women carry the burden of work within the camps, they felt that attention needs to be paid to their requirements.

\section{Conclusion}

The questions that confront the community today are how can women's interests be incorporated in policy and how do women secure these, when natural support networks are destroyed as in Sri Lanka. The situation is aggravated by the stereo-typification of roles and expected behaviour patterns, and there is very little change despite women's contributions and personal losses. Where gender even as an organizational element of humanitarian assistance has been ignored and male-biased policies exist putting women into disadvantageous positions, Sri Lankan women refugees and returnees searching for freedom and protection feel they get neither. The existing mechanisms for their protection are not geared to their needs. It is not sufficient that countries sign international conventions and national laws. States have to go beyond this if women refugees are to be protected.

\section{References}

Balasingham, Adele. 1983. Women and Rerolution: The Role of in Tamil Eelam National Liberation Struggle. Political Committee Liberation Tigers of Tamil Eelam.

Bobb, Dilip, S. H. Venkatramani, and $M$. Rehman. 1987. "There were constraints." India Today, 15 November, 36-39

Diamond, Norma. 1995. "Building Socialism with Chinese Characteristics." In The Women and International Deoelopment Annual, vol. 4, edited by Rita S. Gallen, Anne Ferguson and Janice Harper, 147-96. Boulder Colorado and Oxford: Westview Press.

Dias, Malsiri. 1979. "Socio-Cultural Factors affecting the Status of Women." In Status of Women in Sri Lanka, Swarna Jayaweera et al., 1-15. Colombo: University of Colombo.

Einhorn, Barbara. 1993. Cinderella Goes to Market: Citizenship, Gender and Women's Movement in East Central Europe. London: Verso.

Forbes, Martin S. 1991. Refugee Women. London: Zed Press Ltd.

Gallin, Rita S., Anne Ferguson, and Janice Harper, eds. 1995. The Women and International Development Annual, no. 4. Boulder Colorado and Oxford: Westview Press.

Goody, Jack, and S. J. Tambiah. 1973. Bridewealth and Dowry. Cambridge: Cambridge University Press.

Goonesekera, Savitri. 1990. "Status of Women in the Family Law of Sri Lanka." In Women at the Crossroads: A Sri Lankan Perspective, Sirima Kiribamune and Vidyamali Samarsinghe, 152-81. New Delhi: Vikas Publishing House.

Grossholtz, Jean. 1984. Forging Capitalist Patriarchy: The Economic and Social Transformation of Feudal Sri Lanka and its Impact on Women. Durham N.C.: Duke Press Policy Studies.

Heng, Geraldine. 1997. "A great way to fly: Nationalism, the State, and the Varieties 
of Third World Feminism." In Feminist Genealogies, Colonial Legacies, Democratic Futures, edited by M. Jacqui Alexander and Chandra Talpade Mohanty. New York and London: Routeledge.

Hoole, Rajan et. al. 1990. The Broken Palmyra: The Tamil Crisis in Sri LankaAn Inside Account. Claremont CA.: Sri Lanka Studies Institute

Jayawardena, Kumari. 1986. Feminism and Nationalism in the Third World. London: Zed Books Ltd.

Manushi. 1995. "Refugee and Displaced Women." Gender/Manushi 2, no. 7 (September-October): 3.

Mayotte, Judy A. 1992. Disposable People? The Rights of Refugees. New York: Orbis Books.

Nissan, E. 1996. Sri Lanka Bitter Harvest: Minority Rights Group Report. London: Minority Rights Group.

Rady, Faiza. 1994. "Women's Rights Reviewed." Civil Society: Democratic Transformation of the Arab World 3, no. 33 (October): 8.

Ruiz, Hiram A. 1994. "People Want Peace": Repatriation and Reintegration in Wartorn Sri Lanka. Washington D.C: Immigration and Refugee Service of America.

SEDEC 1993. Journeying Together for Peace: Report ofan Inter-religious Team to Sri Lanka June I-June 20. Colombo: SEDEC

Sharara, Yolla Polity. 1983. "Women and Politics in Lebanon." In Third World-Second Sex: Women's Struggles and National

Liberation, edited by Miranda Davies, 1930. London: Zed Press.

Skjonsberg, Else. 1982. A Special Caste? Tamil Women of Sri Lanka. London: Zed Press.

Tetreault, Marianne. 1993. Women and Revo Iution. Columbia, SC: University of South Carolina Press.

United Nations, Economic and Social Coun cil. 1991. Human Rights Commission. E/CN.

4/1991/SR. 42: 16

Vickers, J., ed. 1993. Women and War. London: Zed Books.

Wickremtunge, Raine. 1995. "Lankan Women: Take Slow but Positive Strides." Liberal Times 3, no. 1, 10-12.

Wijayatilake, Kamalini. 1992. "Rape: Sri Lanka: A Socio-Legal Overview of Rape Laws as a form of Violence against Women." Diva, March, 27-32.

Yuval-Davis, Nira, and Floya Anthias, eds. 1989. Women-Nation-State. London: Macmillan Press. c:J

Refuge, Vol. 16, No.2 (June 1997)

\section{So That Russia be "Saved" \\ Anti-Jewish Violence in Russia: Its Roots and Consequences}

\section{By Tanya Basok and \\ Alexander Benifand}

Toronto: York Lanes Press, 1993

ISBN 1-55014-010-8; 8.5x11 61p; CDN \$9.95

The growing popularity of ultra-nationalism and neo-Nazism in Europe and to some extent in North America is truly alarming, and this publication offers a perceptive analysis of the political trends in Russia and their implications for Russian Jews. It provides an historical analysis of anti-Jewish violence in Russia and poses an important question: can those conditions which resulted in anti-Jewish pogroms at the turn of the century re-emerge today?

Dr. Basok and Dr. Benifand argue in this occasional paper that there is a number of clear indications of the popularity of the anti-Semitic and ultranationalist ideas not only among the masses and nationalist organizations but in the government as well.

Many of those who have been impoverished as a result of the "shock therapy" or who have grown extremely disillusioned with Yeltsin's reform policies, have become attracted to the solutions such as: getting rid of ethnic minorities, especially Jews, territorial expansion of the Russian federation to include the former Soviet republics, the extension of the Russian sphere of influence in Europe and Central Asia, protection of Russian lands (e.g., the Kurile Islands) and the curbing of ethnic nationalism within the Russian federation. Basok and Benifand's insightful analysis is an excellent attempt to understand the rise of ultra-nationalism in Russia.

$$
\text { Available from: }
$$

\section{Centre for Refugee Studies}

Fax: (416) 736-5837

Email: refuge@yorku.ca

\section{Refuge}

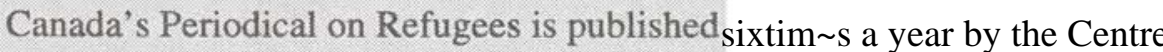
for Refugee Studies, York Univ Toronto.

$$
\text { Available from: }
$$

Centre for Refugee Studies, York University Suite 333, York Lanes, 4700 Keele St. North York ON M3J 1P3

Email: refuge@yorku.ca

http://www.yorku.ca/research/crs 